Review

\title{
Vaccine Potentiation by Combination Adjuvants
}

\author{
Benoît Levast ${ }^{1}$, Sunita Awate ${ }^{1}$, Lorne Babiuk ${ }^{2}$, George Mutwiri ${ }^{1,3}$, Volker Gerdts ${ }^{1,4}$ \\ and Sylvia van Drunen Littel-van den Hurk ${ }^{1,5, *}$
}

1 VIDO-Intervac, University of Saskatchewan, 120 Veterinary Road, Saskatoon, SK S7N 5E3, Canada; E-Mails: benoit.levast@mail.mcgill.ca (B.L.); sua784@mail.usask.ca (S.A.); george.mutwiri@usask.ca (G.M.); volker.gerdts@usask.ca (V.G.)

2 3-7 University Hall, University of Alberta, Edmonton, AB T6G 2J9, Canada;

E-Mail: lbabiuk@ualberta.ca

3 School of Public Health, University of Saskatchewan, 107 Wiggins Road, Saskatoon, SK S7N 5E5, Canada

4 Veterinary Microbiology, University of Saskatchewan, 52 Campus Drive, Saskatoon, SK S7N 5B4, Canada

5 Microbiology and Immunology, University of Saskatchewan, 107 Wiggins Road, Saskatoon, SK S7N 5E5, Canada

* Author to whom correspondence should be addressed; E-Mail: sylvia.vandenhurk@usask.ca; Tel.: +1-306-966-1559; Fax: +1-306-966-7478.

Received: 3 January 2014; in revised form: 22 March 2014 / Accepted: 28 March 2014 / Published: 14 April 2014

\begin{abstract}
Adjuvants are crucial components of vaccines. They significantly improve vaccine efficacy by modulating, enhancing, or extending the immune response and at the same time reducing the amount of antigen needed. In contrast to previously licensed adjuvants, current successful adjuvant formulations often consist of several molecules, that when combined, act synergistically by activating a variety of immune mechanisms. These "combination adjuvants" are already registered with several vaccines, both in humans and animals, and novel combination adjuvants are in the pipeline. With improved knowledge of the type of immune responses needed to successfully induce disease protection by vaccination, combination adjuvants are particularly suited to not only enhance, but also direct the immune responses desired to be either Th1-, Th2- or Th17-biased. Indeed, in view of the variety of disease and population targets for vaccine development, a panel of adjuvants will be needed to address different disease targets and populations. Here, we will review well-known and new combination adjuvants already licensed or currently in
\end{abstract}


development-including ISCOMs, liposomes, Adjuvant Systems Montanides, and triple adjuvant combinations - and summarize their performance in preclinical and clinical trials. Several of these combination adjuvants are promising having promoted improved and balanced immune responses.

Keywords: review; adjuvants; combinations; human clinical trials

\section{Introduction}

Adjuvants are crucial components of vaccines, both for human and animal applications. Adjuvants were initially developed empirically by co-formulating vaccine antigens with a variety of molecules including oils, salts, and carbons. Our growing understanding of the immune system, however, and in particular the innate immune system, has enabled us to develop adjuvants according to a more rational and focused approach rather than through "trial and error." Indeed, adjuvant research has become an integral part of vaccine development. It combines a variety of disciplines, including chemistry, biochemistry, molecular biology, and immunology. Many novel adjuvant technologies have been developed or are in the pipeline for future vaccine candidates. Such novel technologies include combination adjuvants, which consist of more than one adjuvant component and which often act synergistically by stimulating and activating a variety of cells and immune mechanisms. Here, we will review several of the best-known combination adjuvants, including liposomes, ISCOMs, montanides, nanoemulsions and Adjuvant Systems, and summarize their performance in preclinical and clinical trials.

\section{Liposomes}

\section{Cationic Liposomes}

Cationic liposomes have been studied for many years as delivery vehicles/adjuvants. Liposomes protect antigens from degradation, deliver them to antigen presenting cells (APCs), and can be used for mucosal delivery. Many liposomes mediate retention of the vaccine at the site of delivery, and some have immunostimulatory properties, although frequently other compounds such as toll-like receptor (TLR) ligands need to be incorporated for optimal adjuvanticity. Cationic liposomes may contain the following lipids: dimethyldioctadecylammonium (DDA), 3-( $N-\left[N^{\prime}, N^{\prime}\right.$-dimethylaminoethane $]$-carbamoyl) cholesterol (DC-Chol), 1,2-dioleoyl-3-trimethylammonium-propane (DOTAP), $N$-(1-[2,3-dioleyloxy] propyl)- $N, N, N$-trimethylammonium ( $\mathrm{DO}^{\mathrm{TM}} \mathrm{A}$ ), octadecenoyloxy (ethyl-2-heptadecenyl-3-hydroxyethyl) imidazolinium (DOTIM), $N$-palmitoyl-D-erythrospingosyl-1-O-carbamoyl spermine (CCS), 1,2-dioleylsn-glycero-3-ethylphosphocoline (DOEPC) and 3-tetradecylamino-tert-butyl- $N$-tetradecylpropion-amidine (diC14-amidine) (reviewed by [1]). The mechanism of action, while not completely understood yet, is dependent on the nature of the lipids in the formulation, and thus varies widely between different liposomes. One common characteristic related to the cationic charge is the enhanced uptake of DNA or protein by target cells [2]. One of the major drawbacks of liposomes as vaccine delivery vehicles has been their instability. While numerous animal trials have been reported, only recently have liposome- 
based vaccine formulations moved into human clinical trials. This has become possible by the incorporation of helper lipids stabilizing the liposome formulations [2].

DDA has been used as adjuvant in animal trials since 1966 [3], either alone or in combination, and was tested in humans in 1970 and 1973 in combination with tetanus toxoid and alum [4,5]. However, although the vaccine was safe and induced antibody responses, these were not considered robust enough. Consequently, DDA has been combined with other compounds including Emulsigen ${ }^{\circledR}$, monophosphoryl lipid A (MPL), trehalose dibehenate (TDB), monomycoloyl glycerol (MMG) and polyI:C. We combined DDA with Emulsigen and found robust immune responses in cattle [6]. One of the most promising combinations is DDA with TBD (cationic adjuvant formulation [CAF01]). TDB not only stabilized the liposomes, but also significantly enhanced T-cell responses to Mycobacterum bovis Ag85B-ESAT-6 in mice, in particular T cells producing IFN- $\gamma$ and IL-17; this correlated with an increase in IgG2 levels, while IgG1 levels remained the same [7]. The immune responses induced by Ag85B-ESAT-6 formulated with CAF01were long-lived and protective [8]. In addition to mediating depot formation of the vaccine formulation, CAF01 appears to promote influx/activation of DCs into the injection site [9]. Interestingly, in a recent report, the antibody and $\mathrm{CD} 8^{+} \mathrm{IFN}-\gamma$ responses induced by small unilamellar DDA/TDB liposomes were higher than those elicited by multilamellar DDA/TDB liposomes; however, addition of TLR3 or TLR9 ligand enhanced the immune responses, in particular $\mathrm{CD}^{+}$and $\mathrm{CD}^{+} \mathrm{T}$ cells, induced by the multilamellar ones, though this was not found for smaller liposomes [10]. CAF01 has been or is being tested in several phase I clinical trials, one against tuberculosis in combination with Ag85B-ESAT-6 (ClinicalTrails.gov identifier NCT00922363) and two with the HIV peptide cocktail AFO-18 (ClinicalTrials.gov identifier NCT01141205) (Table 1).

MPL (a TLR4 ligand) and MMG, two of the other compounds combined with DDA, are both found in bacterial cell walls and promote Th1-biased immune responses. MPL is derived from LPS, a TLR4 ligand, and when included in an Ag85B-ESAT-6 - DDA liposome formulation, it enhanced protection against tuberculosis both in mice and in cynomolgus monkeys [11,12]. Prominent inflammatory responses to DDA/MPL were observed in subcutaneously immunized mice, including high local levels of pro-inflammatory cytokines, chemokines and a pronounced influx of neutrophils, monocytes/macrophages and activated natural killer cells [13]. The antigen-specific T-cell responses induced by CAF01 (DDA/TDB), DDA/MPL and DDA/MMG in mice were all comparable. However, whereas all three compounds are immunostimulatory, TDB and MMG have the advantage over MPL of stabilizing the liposomes and are thus more promising.

DOTIM was originally used for in vitro and in vivo gene delivery into cells [14]. However, in view of its ability to mediate uptake of DNA into endosomes [15], it was more recently combined with DNA, TLR3 or TLR9 ligand. When co-administered with antigen, the combination of DOTIM and CpG ODN promoted significantly enhanced antigen-specific T-cell responses when compared to delivery of protein with CpG ODN alone [16]. The DOTIM-based liposome in combination with cholesterol and plasmid DNA, designated JVRS-100 adjuvant, promotes pro-inflammatory responses followed by the development of Th1-type responses. Formulations with JVRS-100 have been shown to be efficacious in rodent models against several viruses including hepatitis B virus [17], influenza virus [18], herpes simplex virus-2 (HSV-2) [19], and Rift Valley fever virus [20]. This liposome formulation is also suitable for mucosal delivery as demonstrated in mice where protection from pneumonic tularemia [21] and plague [22] was induced. Currently, JVRS-100 adjuvant is being tested 
in phase I and phase II clinical trials with an influenza split vaccine (ClinicalTrials.gov identifier NCT00936468; ClinicalTrials.gov identifier NCT00662272) (Table 1).

Table 1. Liposomes and TLR agonists: Clinical studies.

\begin{tabular}{|c|c|c|c|c|}
\hline Adjuvant & Phase & Vaccine antigen & Outcomes & References. \\
\hline CAF01 & I & $\begin{array}{l}\text { Mycobacterium } \\
\text { tuberculosis } \\
\text { Ag85B-ESAT-6 }\end{array}$ & No study results posted & $\begin{array}{l}\text { ClinicalTrails.gov identifier } \\
\text { NCT00922363 }\end{array}$ \\
\hline CAF01 & $\mathrm{I}$ & $\begin{array}{l}\text { HIV peptide } \\
\text { cocktail AFO-18 }\end{array}$ & $\begin{array}{l}\text { Induction of T-cell responses } \\
\text { in some of the vaccinees; no } \\
\text { significant changes in viral } \\
\text { load or } \mathrm{CD}^{+} \mathrm{T} \text { cell counts }\end{array}$ & $\begin{array}{l}\text { ClinicalTrials.gov identifier } \\
\text { NCT01141205 [23] }\end{array}$ \\
\hline $\begin{array}{l}\text { JVRS-100 } \\
\text { adjuvant }\end{array}$ & I & Fluzone $^{\circledR}$ & No study results posted & $\begin{array}{l}\text { ClinicalTrials.gov identifier } \\
\text { NCT00662272 }\end{array}$ \\
\hline $\begin{array}{l}\text { JVRS-100 } \\
\text { adjuvant }\end{array}$ & II & Fluzone $^{\circledR}$ & No study results posted & $\begin{array}{l}\text { ClinicalTrials.gov identifier } \\
\text { NCT00936468 }\end{array}$ \\
\hline
\end{tabular}

\section{Immune Stimulating Complexes (ISCOMs)}

Immune stimulating complexes (ISCOM) are ring-like structures containing cholesterol, phosphatidylcholine and saponins, mostly QuilA. ISCOMs have been tested in a variety of species, including small and large animals. The actual ISCOM matrix can directly associate with antigens or be formed first and then added to the formulation at a later time. An important advantage of ISCOMs is their excellent stability for over one year at $4{ }^{\circ} \mathrm{C}$. While the exact mechanism of action is still unclear, ISCOMs have proven to be highly effective when delivered via mucosal surfaces.

ISCOMs interact with dendritic cells (DCs) and can enhance cross-presentation of the incorporated antigen [24], followed by an efficient induction of both $\mathrm{CD}^{+}$and $\mathrm{CD}^{+}$antigen-specific T-cell responses [25]. ISCOM vaccines are known to induce long-lasting antibody responses, a balanced Th1/Th2 response, and induction of cytotoxic $\mathrm{T}$ lymphocytes [26]. ISCOMs have been used in combination with a parenterally administered H5N1 influenza vaccine in healthy adults (PANFLUVAC). In this study, $50 \mu \mathrm{g}$ of a $3 \mathrm{rd}$ Generation ISCOMs was combined with various concentrations of recombinant hemagglutinin (HA). The trial is currently underway (ClinicalTrials.gov identifier NCT00868218) (Table 2). In another clinical trial, ISCOMs have been used with the melanoma vaccine NY-ESO-1 ISCOMATRIX in patients with measurable stage III or IV melanoma. Four doses of the vaccine containing $120 \mu \mathrm{g}$ ISCOMATRIX combined with $100 \mu \mathrm{g}$ of NY-ESO-1 protein were given to patients with advanced melanoma. The trial is currently ongoing. To improve their efficacy, ISCOMs are often used in combination with immune stimulators such as Cholera Toxin A (CTA) subunit or TLR ligands. For example, fusion proteins have been tested including the CTA1-DD, which combines the enzymatically active CTA1-subunit with a B-cell targeting moiety (DD), derived from Staphylococcus aureus protein A [27,28]. Intranasal immunization of mice with hemagglutinin and neuraminidase from influenza strain PR8 resulted in enhanced IgA and CD4 ${ }^{+} \mathrm{T}$ cells [29]. Mucosal IgA and $\mathrm{CD}^{+} \mathrm{T}$-cell response were enhanced after intranasal administration and consequently provided $100 \%$ protection against challenge infection. The mechanism was CTA1 enzyme-dependent 
and designed to target B cells. Another example includes co-formulation of ISCOM and a TLR9 ligand $(\mathrm{CpG} \mathrm{ODN})$. In particular, when used in cancer vaccines, this combination resulted in regression of tumors in a pancreatic cancer mice model using tumor induction by injection of PANC02 tumor cell line transfected by OVA gene [30]. The vaccine, ISCOM+TLR9+OVA antigen, was able to induce strong immunity against the tumor and induce effective memory responses, including a high percentage of $\mathrm{CD}^{+} \mathrm{IFN}^{+} \mathrm{T}$ cells after re-induction of the tumor. Noteworthy, antigen and ISCOM alone or $\mathrm{CpG}$ ODN alone were not efficient to induce anti-tumoral immune response and protection in mice. Another example to improve ISCOMS includes tubular immunomodulatory complexes [31,32] or the association with another adjuvant such as Montanide [33]. For example, when used in combination with a recombinant protein of food and mouth disease virus (FMD) in guinea pigs, higher immune responses were found when ISCOMs and Montanide ISA 206 were used in combination.

Table 2. ISCOMs and IC $31^{\circledR}$ : Preclinical and clinical studies.

\begin{tabular}{|c|c|c|c|c|}
\hline Adjuvants & Phase & Subjects & Comments & References \\
\hline $\begin{array}{l}\text { NY-ESO-1- } \\
\text { ISCOMATRIX }\end{array}$ & II & $\begin{array}{c}\text { Individuals with } \\
\text { advanced melanoma }\end{array}$ & Study ongoing & $\begin{array}{c}\text { ClinicalTrails.gov } \\
\text { identifier NCT } 00518206\end{array}$ \\
\hline $\begin{array}{l}\text { ISCOM and } \\
\text { PANFLUVAC }\end{array}$ & I & Healthy Adults & Study ongoing & $\begin{array}{c}\text { ClinicalTrails.gov } \\
\text { identifier NCT00868218 }\end{array}$ \\
\hline $\begin{array}{c}\text { IC31 }{ }^{\circledR} / \text { Ag85B-ESAT-6 } \\
\text { (TB vaccine) }\end{array}$ & Preclinical & $\begin{array}{l}\text { Neonatal murine } \\
\text { model }\end{array}$ & $\begin{array}{l}\downarrow \text { Bacterial growth, } \\
\text { differentiation of CD4 }{ }^{+} \\
\text {T cells into multifunctional } \\
\text { Th1 and Th17 cells secreting } \\
\text { IL-2, TNF- } \alpha \text { and IFN- } \gamma, \\
\text { antigen-specific DCs } \\
\text { expressing co-stimulatory } \\
\text { molecules CD } 80, \text { CD } 86 \text { and } \\
\text { CD40 in the DLNs }\end{array}$ & {$[34,35]$} \\
\hline $\begin{array}{c}\text { IC } 31^{\circledR} / \text { Ag85B-ESAT-6 } \\
\text { (TB vaccine) }\end{array}$ & Preclinical & $\begin{array}{l}\text { Cynomolgus } \\
\text { macaques }\end{array}$ & $\begin{array}{l}\downarrow \text { Clinical infections and } \\
\text { prevents reactivation of } \\
\text { latent infections }\end{array}$ & {$[36]$} \\
\hline $\begin{array}{c}\text { IC } 31^{\circledR} / \text { Ag85B-ESAT- } 6 \\
\text { (TB vaccine) }\end{array}$ & Preclinical & $\begin{array}{l}\text { Cynomolgus } \\
\text { macaques }\end{array}$ & $\begin{array}{l}\downarrow \text { Clinical infections and } \\
\text { prevents reactivation of } \\
\text { latent infections }\end{array}$ & {$[36]$} \\
\hline $\begin{array}{l}\text { IC31 } 1^{\circledR} / \text { Ag85B-ESAT- } 6 \\
\text { (TB vaccine) }\end{array}$ & $\mathrm{I}$ & $\begin{array}{c}\text { Healthy } \\
\text { mycobacterially } \\
\text { naïve individuals }\end{array}$ & $\begin{array}{l}\text { Potent and persistent } \\
\text { antigen-specific IFN- } \gamma^{+} \\
\text {T-cell responses, sustained } \\
\text { for } 2.5 \text { years }\end{array}$ & [37] \\
\hline $\begin{array}{c}\text { IC } 31^{\circledR} / \text { Ag85B-ESAT-6 } \\
\text { (TB vaccine) }\end{array}$ & I & $\begin{array}{l}\text { Prior TB-infected } \\
\text { individuals }\end{array}$ & $\begin{array}{l}\text { Strong antigen-specific } \\
\text { T-cell responses, sustained } \\
\text { for } 32 \text { weeks }\end{array}$ & {$[38]$} \\
\hline $\begin{array}{c}\text { IC } 31^{\circledR} / \mathrm{H} 1 \mathrm{~N} 1 \text { (Influenza } \\
\text { vaccine) }\end{array}$ & Preclinical & Young and aged mice & $\begin{array}{l}\uparrow \mathrm{HI} \text { titers, IgG2a Abs and } \\
\text { IFN- } \gamma \text { producing CD4 }{ }^{+} \\
\mathrm{T} \text {-cell responses, sustained } \\
\text { for } 200 \text { days after a single } \\
\text { dose vaccination }\end{array}$ & [39] \\
\hline $\begin{array}{l}\mathrm{IC} 31^{\circledR} / \mathrm{HSV}-2(\text { Genital } \\
\text { herpes vaccine) }\end{array}$ & Preclinical & Mice & $\begin{array}{l}\text { High neutralizing } \\
\text { HSV-specific Ab responses } \\
\text { and splenic IFN- } \gamma \text { responses }\end{array}$ & [40] \\
\hline
\end{tabular}




\section{Montanide}

Montanide-based adjuvants have been used in both veterinary and human vaccines. These oil-based formulations have been successfully commercialized and are now available for animals in a vaccine against FMD. For human application, Montanide-based therapeutic vaccines have been developed for cancer [41]. The mechanism of action for this oil-based adjuvant includes the formation of a depot at the injection site, which enables the slow release of the antigen. Formulated antigens are concentrated and protected against degradation while phagocytosis is stimulated.

Montanides can be improved by combining them with other adjuvants or immune modulators. An

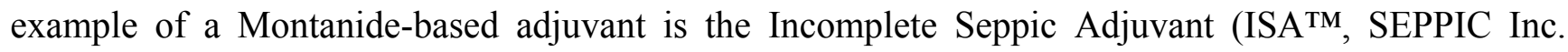
Fairfield, NJ, USA), which acts as oil-emulsion adjuvant, and which has been tested in combination with a number of experimental vaccines including a malaria vaccine [42,43]. Also, Montanides and ISCOMs were tested with a recombinant protein vaccine for FMD virus using guinea pigs [33]. Interestingly, this combination showed the greatest promise in inducing early and long-term protection. Since activation of the innate immune system is one of the best ways to stimulate a systemic immune response, Montanides have been tested in combination with TLR ligands including LPS for TLR4, Poly (I:C) for TLR3, Imiquimod for TLR7 and CpG ODN for TLR9.

Montanides have been evaluated in several clinical trials. For example, the Montanide ISA 51 was tested in combination with cancer antigens and cytokines including an evaluation of the effects of local Granulocyte-Macrophage Colony Stimulating Factors (GM-CSF) on skin DCs in melanoma patients [44,45]. Interestingly, low doses of GM-CSF did not enhance its immunogenicity [46]. Montanides and Poly (I:C) have been used for a phase I trial on 28 advanced ovarian cancer patients [47]. Using overlapping long peptides (OLP) from the human cancer-testis antigen NY-ESO-1, patients were treated with OLP alone, OLP+Montanide or OLP+Montanide+polyIC LC. No NY-ESO-1specific antibodies or $\mathrm{CD}^{+} \mathrm{T}$ cells were detected after vaccination with OLP alone, though they were found in $46 \%(\mathrm{Ab})$ and $62 \%\left(\mathrm{TCD}^{+}\right)$patients respectively after vaccination with OLP+Montanide, and in $91 \%$ (both) patients respectively after vaccination with OLP+Montanide+Poly-ICLC. These results strongly indicate the importance of the adjuvants, especially when combined in a single formulation. In another study in melanoma patients, imiquimod was added to a combination of viral nanoparticles coated with $\mathrm{CpG}$ ODN and Montanide. The combination resulted in greater memory and effector $\mathrm{CD}^{+} \mathrm{T}$ cells responses [48]. Finally, $\mathrm{CpG}$ ODN was assessed to be efficient in cancer vaccine therapy with the same antigen NY-ESO-1 [49]. Treated patients were able to produce specific CD8 ${ }^{+} \mathrm{T}$ cells. Interestingly, for three different leukemia-associated antigens, no positive results were found using the CpG-Montanide combination [50]. Although only tested in very few subjects, it underlines the importance of the choice of adjuvants and antigen. Furthermore, Montanides have been tested in combination with very small size proteoliposomes (VSSP) in the treatment of prostate cancer [51]. VSSP is already included in a combination of adjuvants. However, the authors showed that association of a Gonadotropin Releasing Hormone (GnRH)-peptide with VSSP and Montanide ISA-51 was able to reduce size and weight of both testicles and prostate in a male rat model. 


\section{5. $\operatorname{IC31}^{\circledR}$}

Polycationic peptides enhance cellular uptake of proteins or bacterial DNA by cells [52]. IC30, which consists of poly-L-arginine, has been shown to efficiently transport tumor antigens to APCs [53]. IC30 adjuvant activity involves recruitment of MHC class II $(+)$ cells at the injection site and migrating antigen-specific cells to the draining lymph nodes. Subcutaneous injection of IC30 with tumor antigen-derived peptide antigens led to antigen-specific T-cell responses, which were detectable for more than four months after injection suggesting a depot effect [54].

Based on the ability of cationic compounds to enhance uptake, IC30 was combined with CpG ODN, a TLR9 agonist. The combination of IC30 and CpG ODN induced stronger antigen-specific $\mathrm{T}$ cells responses, which were detectable even one year after injection [55]. Apart from IC30, various other cationic antimicrobial peptides have been developed to treat infections. The potential of an antibacterial cationic peptide $\mathrm{KLKL}_{5} \mathrm{KLK}(\mathrm{KLK})$ to induce humoral and Th2-type immune responses against co-administered antigens after prime-boost immunizations have been reported [56]. This led to development of the novel adjuvant IC $31^{\circledR}$, where the potential of KLK to induce Th2 responses and that of TLR9 agonist to induce Th1 responses was exploited. The novel bi-component vaccine adjuvant, IC $31^{\circledR}$ (Intercell AG, Vienna, Austria) consists of a vehicle based on KLK and the TLR9 agonist ODN1a. ODN1a, a single-stranded DNA-phosphodiesther, consists of repeats of the dinucleotides deoxyinosine and deoxycytosine [oligo-d(IC)13] [57]. CpG ODN was replaced by ODN1a due to potential side effects induced by $\mathrm{CpG}$ ODN such as production of systemic pro-inflammatory cytokines [58]. The preclinical studies with IC $31^{\circledR}$ in various disease models in animals have shown potent immunogenicity and protection efficacy including antigen-specific humoral and cellular responses. These encouraging results pave the way for the novel combination adjuvant IC $31^{\circledR}$ into clinical trials against various viral and bacterial infections (Table 2).

The two components of IC $31^{\circledR}$, KLK and ODN1a, act via different mechanisms. Subcutaneous injection of fluorescent-labeled OVA, KLK, and ODN1a in mice led to depot formation at the site of injection, which was detectable up to 58 days after injection. However, co-administration of fluorescent-labeled OVA and ODN1a resulted in rapid clearance from the injection site, indicating the potential of KLK to induce a depot at the injection site [59]. IC $31^{\circledR}$ formed a stable complex that protected both adjuvants and antigens from degradation leading to continuous stimulation of the immune system and induction of specific immune responses. In addition, co-administration of OVA with IC31 ${ }^{\circledR}$ in TLR9 and MyD88 double knock-out mice completely abolished antigen-specific immune responses suggesting that the immune-stimulatory effects of IC31 ${ }^{\circledR}$ depends on TLR9/MyD88 signaling pathways [59]. Since cationic peptides have the potential to enhance uptake of bacterial DNA, KLK may serve as a delivery vehicle to transport ODN1a inside the murine and human DCs to interact with intracellular TLR9 receptors [60]. Further engagement of TLR9 leads to NF- $\mathrm{B}$ activation via the adaptor molecule MyD88, thereby triggering the immune responses.

Being the only professional APCs, DCs are specialized in processing and presenting antigens to naïve $\mathrm{T}$ cells and induce activation of antigen-specific immune responses [61]. Presentation of antigens on MHC molecules, expression of co-stimulatory molecules, and secretion of cytokines are essential for optimal activation of naïve $\mathrm{T}$ cells. IC $31^{\circledR}$ has been shown to upregulate the surface expression of MHC class I and co-stimulatory molecules CD80, CD86, CD40 and CD54 on murine 
bone-marrow dendritic cells (BMDCs). Further, in in vitro studies using OVA-pulsed BMDC, IC31 ${ }^{\circledR}$ induced antigen-specific $\mathrm{CD}^{+} \mathrm{Th}$ cells proliferation and differentiation of OVA-specific CD4 ${ }^{+}$ $\mathrm{T}$ cells into antigen-specific Th1 cell (IFN- $\gamma$ producing) and Th2 cell (IL-4 producing) types [59]. In vivo studies suggests involvement of plasmacytoid DCs (pDCs) in the adjuvant activity of IC $31^{\circledR}$, as highly activated pDCs with enhanced expression of co-stimulatory molecules were found in the draining lymph nodes of mice injected with IC $31^{\circledR}$. In addition, IC $31^{\circledR}$ induced potent cytotoxic effector T lymphocytes that killed target cells in an antigen-specific manner [59].

\section{Triple Combination Adjuvant}

Various combination adjuvants consisting of a variety of molecules have been developed in recent years and are currently being tested in preclinical trials. This includes both dual and triple combinations and includes polymers such as poly(lactic-co-glycolic) acid, chitosan and polyphosphazenes [62,63]. A novel combination adjuvant was developed consisting of innate defense regulator peptide (IDR), polyphosphazene (PP) and TLR ligand, either CpG ODN or PolyI:C. Innate defense regulator peptides are short peptides that stimulate both innate and adaptive immunity and by activating antigen-presenting cells link innate and adaptive immunity. Innate defense regulator peptides are involved in a variety of immune functions including innate immune activation, wound healing, cell recruitment and to some extent, direct antimicrobial control [64-66]. Polyphosphazenes are synthetic polymers that are used as carriers for adjuvants and vaccine antigens and that on their own have modest adjuvant activity $[67,68]$. However, when combined with immune stimulators such as $\mathrm{CpG}$ ODN or PolyIC these molecules can form complexes that become highly immunogenic. The combination adjuvant was developed through screening of hundreds of molecules and testing in human, murine and porcine cells. The most promising candidates were assessed in vivo in a variety of animal species including cattle, pigs, sheep, mice and cotton rats in combination with a variety of vaccine antigens. Interestingly, when co-formulated, the adjuvants induced strong expression of cytokines and chemokines - such as Grola, TNF- $\alpha$, IL- 6 - in stimulated cells and displayed a strong synergistic effect when used in combination [69]. Furthermore, the adjuvant platform can be formulated into microspheres that range in size from $100 \mathrm{~nm}$ to $2 \mu \mathrm{m}$ and that enhanced the mucosal immune response following intranasal immunization. Interestingly, the proper selection of innate defense regulator peptide was found to be critical as some of these peptides could actually decrease the immune response [70]. These microparticles could be lyophilized and stored at room temperature for more than a year without any loss of specific activity [71]. A synergistic effect of the TLR agonist, IDR and PP on the magnitude of the humoral, and specifically cell-mediated, immune responses was demonstrated in murine and bovine models [72-74]. The adjuvant platform was highly effective against a variety of infectious diseases. For example, when combined with the Bordetella pertussis antigens pertussis toxoid, filamentous hemagglutinin, and/or pertactin, the vaccine induced protective immune responses in both mice and pigs against lethal infection with B. pertussis [75]. The vaccine induced an earlier onset and longer duration than existing commercial vaccines and was effective already after a single immunization even in the presence of maternal antibodies. Furthermore, the vaccine shifted the immune response to a more balanced or Th1-type response [76,77], Similarly, when the same adjuvant combination was used with a recombinant fusion protein of respiratory syncytial virus, strong immune responses were found that provided protection against infection in mice, 
cotton rats and lambs [78,79], When used in combination with chlamydia antigens or influenza virus antigens, strong immune responses were detected in vaccinated animals $[69,80]$.

\section{Adjuvant Systems}

Adjuvant systems $^{\mathrm{TM}}$ (GlaxoSmithKline (GSK)) are various combinations of classical adjuvants and immunostimulators specifically designed to tailor the adaptive immune responses against specific pathogens in a target population including children, elderly and immunocompromised individuals. Various adjuvant systems have been developed and a few are in clinical trials. AS03 and AS04 have already been licensed for use in humans. AS03 was approved for H5N1 prepandemic and H1N1 pandemic influenza vaccines and AS04 for human papilloma virus (HPV) (Cervarix ${ }^{\mathrm{TM}}$ ) and hepatitis B virus (HBV) $\left(\right.$ Fendrix $^{\circledR}$ ). AS04 was also licensed for herpes simplex virus (HSV) but was recently terminated due to low efficacy in clinical trials [81].

\subsection{AS04}

The TLR4 agonist lipopolysaccharide (LPS) is a potent adjuvant but it is very toxic and causes septic shock. MPL is a "detoxified" derivative of LPS isolated from the Gram-negative bacterium Salmonella Minnesota R595 strain. While less toxic, MPL retains the immunostimulatory properties of LPS. AS04 (Adjuvant System 04), is a combination adjuvant containing MPL and aluminum hydroxide. AS04 is licensed for use in HPV and HBV vaccines. Another promising HSV vaccine, gD2/AS04, showed better immune protection and significantly reduced the viral load and viral shedding when compared to the gD2 vaccine adjuvanted with aluminum salts alone in guinea pigs [82]. In clinical trials, gD2/AS04 tested in HSV-1 and HSV-2 seronegative women showed 73\% and 74\% efficacy respectively against genital herpes infections [83]. However, in a randomized, double-blind phase III clinical trial conducted in 8323, 18-30 year-old, women seronegative for HSV-1 and HSV-2, the HSV-2/AS04 vaccine efficacy was only $20 \%$ and it failed to protect the women from genital disease [84].

When combined with alum, MPL still retains its ability to interact with TLR4 and activate innate immune responses. This leads to activation of NF- $\kappa \mathrm{B}$ and transient production of pro-inflammatory cytokines (IL-6, TNF- $\alpha$, and IFN- $\gamma$ ) and chemokines, such as CCL2 and CCL3 at the injection site [85]. CCL2 and CCL3 can promote recruitment of other immune cells, especially monocytes and macrophages, and activation and maturation of APCs, especially DCs at the site of injection. Increasing numbers of mature DCs migrate to the draining lymph nodes and interact with $\mathrm{T}$ cells to trigger the induction of antigen-specific adaptive immune responses [86]. MPL induces Th1-type immune responses by promoting IFN- $\gamma$ production by antigen-specific $\mathrm{CD}^{+} \mathrm{T}$ cells, hence overcoming the shortcoming of alum, which induces only Th2-type immune responses. When combined with alum, MPL-induced stimulation of pro-inflammatory cytokines was neither improved nor inhibited by alum. However, alum did prolong the local cytokine responses induced by MPL at the injection site [85]. 


\section{2. $A S 03$}

Since water-in-oil emulsions were too reactogenic for use in humans, GSK developed AS03, an oil-in-water emulsion. AS03 consists of DL- $\alpha$-tocopherol, squalene, and polysorbate 80 . Oil-in-water emulsions are less reactogenic and have better safety profiles. One such oil-in-water emulsion is MF59, which has been approved for human use in European countries. MF59 consist of squalene, polysorbate 80 and Span 85 and the only difference between MF59 and AS03 is the presence of $\alpha$-tocopherol, a biodegradable and immunostimulatory oil. $\alpha$-tocopherol is a form of vitamin $\mathrm{E}$ that is easily absorbed in human body [87]. Squalene, another component of AS03, is normally synthesized in the liver and found in various organs with highest secretion by human skin. Squalene is an essential intermediate molecule in the biosynthesis pathways of steroid hormone, cholesterol and vitamin D [88]. The last component of AS03, polysorbate 80 (polyoxy-ethylene sorbitan-20 monooleate) is added to stabilize the emulsion. It is a semi-synthetic molecule derived from naturally occurring fatty acid that is largely used as aqueous formulation stabilizer in the food and pharmaceutical industries [89].

Injecting antigen and AS03 $72 \mathrm{~h}$ apart or in different limbs resulted in reduced influenza-specific antibody titers suggesting that $\mathrm{AS} 03$ adjuvant activity depended on the spatial and temporal co-localization with the antigen [90]. AS03 induced production of NF-kB, and subsequently cytokines and chemokines, including CCL2, CCL3, IL-6, CSF3 and CXCL1 in muscle and the draining lymph nodes of mice after injection [90]. Similar to alum and MF59, DCs were not directly activated by AS03. Antigen-loaded DCs, monocytes and granulocytes were found to migrate to the draining lymph nodes after injection of AS03. H5N1 split-virion A/Vietnam/1194/2004 influenza vaccine with AS03(A) resulted in increased production of polyfunctional $\mathrm{H} 5 \mathrm{~N} 1$-specific $\mathrm{CD}^{+} \mathrm{T}$ cells in volunteers aged 18-60 years [91]. An increase in antigen-specific $\mathrm{CD}^{+} \mathrm{T}$ cells might be responsible for persistence of increased antibody responses and induction of memory B cell responses by AS03.

\section{3. $\mathrm{ASO2}$}

AS02 is a combination of oil-in-water emulsion with MPL and QS21 (MPLA+QS21+o/w emulsion) and was initially developed for malaria vaccines. QS21 has been shown to induce antigen-specific antibody, cell-mediated and CTL responses, including development of immunological memory in nonhuman primates [92-94]. AS02 was used for development of the RTS,S candidate malaria vaccine, which includes the circumsporozoite protein (CSP) as a vaccine antigen. RTS,S consists of a hybrid protein that includes a portion of the CSP fused to the hepatitis B virus surface antigen (HBsAg), which is expressed together with unfused HBsAg in genetically engineered yeast cells [95]. In phase I/IIa clinical trials, AS02-based malarial vaccines provided better protection (protecting six out of seven individuals) compared to AS03 and AS04-based formulations in malaria-naïve individuals challenged with $P$. falciparum through bites from mosquitoes [96]. Recombinant AS02-based malaria vaccine has been tested for safety, immunogenicity and efficacy in various phase I clinical trials. Apart from malaria vaccines, AS02 has been tested with tuberculosis, hepatitis B, HIV vaccines and cancer immunotherapy (Table 3). 
Table 3. Adjuvant system (AS): Clinical studies.

\begin{tabular}{|c|c|c|c|c|}
\hline Adjuvants & Phase & Subjects & Summary & References \\
\hline \multirow[t]{4}{*}{ AS04/HPV-16/18 (Cervarix $\left.{ }^{\mathrm{TM}}\right)$} & III & Girls and women (10-75 years) & $\mathrm{Ab}$ responses in serum and cervicovaginal secretions up to 36 months & [97] \\
\hline & III & $>8,000$ women $(15-25$ years $)$ & $\begin{array}{l}\text { Vaccine efficacy } 92.9 \% \text { against cervical intraepithelial neoplasia grade } 2 \text { and above } \\
\left(\mathrm{CIN} 2^{+}\right) 34.9 \text { months post vaccination and high vaccine efficacy against } \mathrm{CIN} 2^{+} \\
\text {associated with } 12 \text { non-vaccine oncogenic strains (cross-protection) }\end{array}$ & [98] \\
\hline & IIIb & $\begin{array}{l}\text { HIV-seronegative young African girls } \\
\qquad(10-25 \text { years })\end{array}$ & $\begin{array}{l}100 \% \text { seroprotection, which sustained up to } 12 \text {-month post-vaccination, high } \\
\text { neutralizing Abs and total IgG titers sustained for } 8.4 \text { years post-vaccination }\end{array}$ & {$[99,100]$} \\
\hline & $\mathrm{IIIb}$ & Young girls $(9-15$ years $)$ & $\begin{array}{l}\text { Co-administered HPV-16/18/AS04 with inactivated hepatitis A and B (HAB) or } \\
\text { dTpa-IPV: immunogenicity was no inferior than any of the vaccine alone }\end{array}$ & {$[101]$} \\
\hline AS04/HBV (Fendrix ${ }^{\mathbb{B}}$ ) & & $\begin{array}{l}\text { Elderly, immunocompromised and renal } \\
\text { insufficiency patients }\end{array}$ & $\begin{array}{l}\text { Rapid and high seroprotection at } 3 \text { month ( } 74 \% \text { vs. } 52 \%) \text { and } 3 \text { year }(73 \% \text { vs. } 52 \%) \\
\text { compared to HB-alum vaccinated individuals }\end{array}$ & [102] \\
\hline AS03 + Influenza A (H1N1 vaccine) & II and III & $\begin{array}{c}\text { Volunteers ( } 18-60 \text { years }) \text {, high-risk } \\
\text { elderly }(61-88 \text { years) and children ( } 3-9 \\
\text { years) }\end{array}$ & $\begin{array}{l}\text { Higher seroconversion levels and } 4 \text {-fold Ag-sparing effect compared to nonadjuvanted } \\
\text { vaccine, } \uparrow \mathrm{H} 1 \mathrm{~N} 1 \text { specific } \mathrm{CD} 4^{+} \mathrm{T} \text { cells }\end{array}$ & [103-105] \\
\hline AS03 + Influenza A (H1N1 vaccine) & II & Children (6 months -12 years) & Higher immunogenicity compared to nonadjuvanated vaccines & {$[106]$} \\
\hline $\begin{array}{l}\text { AS03 + H1N1 influenza pandemic } \\
\text { vaccine } 2009\end{array}$ & & Multiple populations & Vaccine efficacy: $72 \%-97 \%$ & {$[107]$} \\
\hline \multirow[t]{2}{*}{ AS02+RTS,S (Malaria vaccine) } & $\mathrm{IIb}$ & 131 semi-immune adults & Vaccine efficacy: $71 \%$ in $9 \mathrm{wks}$, strong $\mathrm{Ab}$ and T-cell responses to CSP & {$[108]$} \\
\hline & $\mathrm{IIb}$ & 2,022 children ( $1-4$ years) & $\begin{array}{l}\text { Vaccine efficacy: } 29.9 \% \text { for first clinical episodes and } 57.7 \% \text { for severe malaria. } \\
\text { Vaccine efficacy: } 48.6 \% \text { at } 18 \text { months for several malaria cases }\end{array}$ & [109] \\
\hline $\mathrm{AS} 02+\mathrm{Mtb} 72 \mathrm{~F}$ (TB vaccine) & I & $\begin{array}{l}\text { Purified Protein Derivative } \\
\text { (PPD)-negative adults (18-40 years) }\end{array}$ & $\begin{array}{l}\uparrow \text { Humoral and polyfunctional } \mathrm{CD} 4^{+} \mathrm{T}-\mathrm{cell} \text { responses expressing CD40L, IL-2, } \\
\mathrm{TNF}-\alpha \text { and IFN- } \gamma \text {, sustained for } 9 \text { months and } 1 \text { year after primary and booster } \\
\text { immunization, respectively }\end{array}$ & {$[110]$} \\
\hline $\mathrm{AS} 02+\mathrm{HBV}$ & III & $\begin{array}{l}450 \text { healthy individuals Renal } \\
\text { insufficiency patients; inprior HB } \\
\text { vaccinated individuals }\end{array}$ & $\begin{array}{l}\text { High seroprotection rates after first }(75.9 \%) \text { and second vaccine doses }(99.7 \%) \\
\text { Seroprotection rate }(76.9 \%) \text { Seroprotection rates were } 89.0 \% \text { one month } \\
\text { post-booster vaccination }\end{array}$ & {$[111,112]$} \\
\hline AS02 + MAGE-A3 & & $\begin{array}{l}\text { Advanced tumor patients, Lung cancer } \\
\text { patients }\end{array}$ & $\begin{array}{l}\text { Anti-MAGE-A3-specific Ab responses in } 96 \% \text { of the advanced tumor patients and } \\
30 \% \text { patients showed } \uparrow \text { IFN- } \gamma \text { responses }\end{array}$ & {$[113,114]$} \\
\hline AS01/RTS,S (malaria vaccine) & Preclinical & Rhesus monkeys & $\uparrow \mathrm{Ag}$-specific $\mathrm{Ab}$ and IFN- $\gamma$ producing Th1-type responses & {$[115,116]$} \\
\hline AS01/MSP-1 (malaria vaccine) & IIa & 102 healthy human volunteers & $\begin{array}{l}\text { Vaccine efficacy was higher }(50 \%) \text { compared to RTS,S/AS02A vaccine; } \uparrow \text { CSP-specific } \\
\text { IgG titers and polyfunctional } \mathrm{CD} 4^{+} T \text { cells expressing IL- } 2, \text { IFN- } \gamma, \text { TNF- } \alpha \text {, or CD } 40 \mathrm{~L}\end{array}$ & [117] \\
\hline AS01/M72 (TB vaccine) & $\mathrm{I} / \mathrm{II}$ & 110 PPD-negative human volunteers & Vaccine specific Th1 $\mathrm{CD}^{+}{ }^{+} \mathrm{T}$-cell responses compared to M72/AS02 vaccine & [118] \\
\hline AS01/M72 (TB vaccine) & II & 540 children, aged $5-17$ months & $\mathrm{RTS}, \mathrm{S} / \mathrm{AS} 01_{\mathrm{E}}$ induced higher $\mathrm{CD} 4^{+} \mathrm{T}$-cell responses as compared to RTS,S/AS02D & [119] \\
\hline AS01/F4 (HIV-1 vaccine) & $\mathrm{I} / \mathrm{II}$ & 180 healthy volunteers ( $18-40$ years) & $\begin{array}{l}\text { High frequencies of polyfunctional CD4 }{ }^{+} \text {T-cell responses characterized by CD } 40 \mathrm{~L}, \text { IL- } 2 \text { in } \\
\text { combination with TNF- } \alpha \text { and/or IFN- } \gamma \text {, which persisted for } 44 \text { days post-vaccination. }\end{array}$ & [120] \\
\hline
\end{tabular}




\subsection{ASO1}

Malaria vaccine adjuvanted with AS02 has shown great promise. However, to further increase the efficacy and to eliminate the infected hepatocytes, the AS01B adjuvant system has been evaluated by GSK. The AS01 adjuvant system is a liposomal formulation comprised of immune-stimulants MPL and QS21 (MPLA+QS21+a liposomal suspension). When tested in rhesus monkeys, RTS,S/AS01 elicited higher antigen-specific antibody and IFN- $\gamma$ producing Th1-type responses compared to any other adjuvant formulations [116]. Even when tested with MSP-1 antigen, AS01B adjuvanted vaccine elicited the highest anti-MSP1 antibodies and strong Th1 responses characterized by high numbers of IFN- $\gamma$ secreting cells that were sustained for 24 weeks after final vaccination [121]. A RTS,S/AS01 malaria vaccine was more efficacious than a RTS,S/AS02A vaccine, inducing increased IgG titers and polyfunctional $\mathrm{CD}^{+}{ }^{+} \mathrm{T}$ cells expressing IL-2, IFN- $\gamma$, TNF- $\alpha$, or CD40L [117] (Table 3). In a more recent clinical trial in children, $\mathrm{RTS}, \mathrm{S} / \mathrm{AS} 01_{\mathrm{E}}$ also induced higher $\mathrm{CD} 4{ }^{+} \mathrm{T}$-cell responses as compared to RTS,S/AS02D [119].

In view of the strong induction of cell-mediated immunity, AS01B was also evaluated in a human clinical trial with a TB vaccine in comparison to AS02. In this study, M72 antigen was formulated with either AS02 or AS01. While both M72/AS01 and M72/AS02 had an acceptable safety profile and elicited robust polyfunctional M72-specific $\mathrm{CD}^{+}{ }^{+} \mathrm{T}$-cell and antibody responses, the highest $\mathrm{CD} 4^{+}$ T-cell responses were induced by M72/AS01 [118]. Thus, the M72/AS01 was chosen for further vaccine development.

\section{Nanoemulsions}

Nanoemulsions have a mean droplet diameter of 50-1,000 $\mathrm{nm}$ and are particularly suited to mucosal delivery. Although not as extensively studied as liposomes, one nanoemulsion is licensed and several have progressed to human clinical trials. One of the best characterized nanoemulsions is MF59, an oil-in-water emulsion of $\sim 250 \mathrm{~nm}$ consisting of the metabolizable oil squalene, Tween-80 and Span 85 (reviewed in [122]). MF59 has an acceptable safety profile and was licensed in 1997 in Europe for an influenza vaccine, thereby becoming the first adjuvant licensed for human applications since alum. MF59 creates a depot effect and directly activates immune cells [123].

Two other oil-in-water nanoemulsions, when formulated with smallpox, HIV-1, influenza, or hepatitis $\mathrm{B}$ antigens and delivered intranasally, mediated the production of not only robust virus neutralizing antibodies, but also IFN- $\gamma$ and TNF- $\alpha$, as well as elevated IgG2a and mucosal IgA levels. These oil-in-water emulsions, designated $\mathrm{W}_{20} 5 \mathrm{EC}$ and $\mathrm{W}_{80} 5 \mathrm{EC}$, consist of $1 \%$ cetyl pyridum chloride (CPC), 5\% Tween 20 or Tween $80,8 \%$ ethanol in $64 \%$ soybean oil and $22 \%$ water (NanoBio Corporation, Ann Arbor, MI, USA). When formulated with smallpox, HIV-1, influenza, or hepatitis B antigens and delivered intranasally, these adjuvants mediated the production of not only robust virus neutralizing antibodies, but also IFN- $\gamma$ and TNF- $\alpha$, as well as elevated IgG2a and mucosal IgA levels. $\mathrm{W}_{80} 5 \mathrm{EC}$ was evaluated in a human clinical trial with Fluzone ${ }^{\circledR}$, which demonstrated that this adjuvant is well tolerated. Volunteers received a single intranasal dose with increasing antigen and adjuvant amounts. The highest dose $(10 \mu \mathrm{g})$ of antigen in combination with $20 \% \mathrm{~W}_{80} 5 \mathrm{EC}$, induced increased 
serum hemagglutination inhibition antibodies reactive with three influenza strains, as well as antigenspecific IgA in the nasal wash [124].

MF59 has been combined with either a CpG ODN or a TLR4 agonist, E6020, in an influenza soluble trivalent egg-derived antigen formulation. While addition of CpG ODN or E6020 to MF59 did not increase influenza-specific antibody titers, a shift towards a more Th1-biased response was observed which suggests that co-formulation of MF59 with a TLR ligand may tailor the immune response to be more Th1 biased [125]. In contrast, co-delivery of E6020 within MF59 enhanced the magnitude of the antibody levels, as well as increased the breadth of the response, when formulated with Men B antigens or Men ACWY-CRM conjugate vaccine [126]; furthermore, addition of either E6020 or CpG ODN to the Men B vaccine in MF59 increased the percentage of antigen-specific cells secreting IL-2, TNF- $\alpha$ and IFN- $\gamma$, again demonstrating a shift towards a Th1 bias. Recently, CpG ODN was shown to both enhance the hemagglutination and virus neutralization titers, and specifically increase the IgG2a levels, when added to a trivalent influenza vaccine (FCC) formulated in MF59. In addition, a much more pronounced Th1 profile, characterized by a potent IFN- $\gamma$ response, was induced when CpG ODN was added [127]. This effect of addition of the TLR agonists is of particular significance not only for these two vaccines, but also in general when a particular Th bias is needed for protection.

\section{Conclusions}

Many of the vaccines that have been recently developed, or will be in the future, consist of highly pure pathogen-derived antigens. This approach is necessary for vaccine development against live-threatening infectious diseases and cancers. For these antigens to induce robust immune responses, formulation with adjuvants is critical. Adjuvants can enhance the speed and magnitude of the development of immune responses, reduce the amount of antigen and/or vaccinations needed, increase cross-protection and reduce non-responsiveness, in particular of specific populations such as the very young or elderly. In view of these multiple roles, the current trend in vaccine formulation against both cancer and infectious diseases is to include at least one and often multiple components to engage PRRs, and thus activate the innate immune response, as well as at least one compound that stabilizes or targets antigens to the appropriate immune cells. Engagement of PRRs by their ligands is critical for induction of the innate immune response which then directs the adaptive immune response to be either Th1-, Th2- or Th17-biased. This ability to tailor the immune response is particularly important for vaccine development against difficult targets such as chronic bacterial or viral infections and cancer. Several classes of PRRs have been identified, including TLRs, NOD-like receptors (NLR), RIG-I-like receptors (RLRs) and C-type lectin receptors (RLRs). As described in this review, TLR agonists have been most extensively studied as adjuvants ands shown to be very promising. The TLR agonists often act synergistically with other classes of adjuvants used in the formulation or even with other TLR or NLR agonists. In fact, it is now known that one of the most effective vaccines, the live-attenuated yellow fever vaccine, activates multiple DC subsets through TLR2, TLR7/8 and TLR9, which leads to a robust balanced immune response. Aluminum salts and muramyl-dipeptides are two examples of NLR agonists used in licensed vaccines and clinical trials, respectively, and as more agonists of these additional classes of PRRs are identified, we can expect more to be tested as adjuvants. 
Currently there are four licensed vaccines that contain multiple TLR agonists, BCG that contains TLR2 and TLR4 agonists, Cervarix and Fendrix that contain alum and MPL, and Cadi-05 (Immuvac) (Mycobacterium indicus pranii) against leprosy. This demonstrates that it is possible to overcome any real or perceived disadvantages of multi-adjuvanting. One problem is the increased expense and complexity of manufacturing and formulating a vaccine antigen with multiple adjuvants. Another major issue is the potential for more adverse effects in the recipients; however, the individual components of a combination adjuvant often can be used at a lower concentration than when administered as a stand-alone adjuvant. This may actually reduce side-effects and production costs. A third hurdle is the concern of regulatory agents with novel adjuvants and combinations in particular, which hopefully will become more easily alleviated once more information about the mechanisms of action of adjuvants - and vaccines in general - is gained. For instance, the mechanisms of action have been elucidated for several adjuvants, including MF59, alum, MPL (reviewed in [128]); however, efforts in this area, specifically for combination adjuvants, need to be expanded. Systems biology can now be applied to elucidate molecular signatures to new vaccine candidates in comparison to very effective current vaccines such as the yellow fever vaccine and thus predict efficacy and safety [129]; this is another new area of research that will assist in licensing new vaccine formulations.

In this review we summarized recent and relevant information about many known and new adjuvant combinations including ISCOMs, liposomes, Adjuvant Systems, Montanides and triple combination adjuvants is clear that combinations of adjuvants have multiple advantages, and are critical to achieve the desired degree of vaccine efficacy against many new, challenging disease targets. Furthermore, there is strong evidence supporting inclusion of at least one PRR agonist. As these pathogens target different organs and tissues and cause different types of pathogenesis, there likely will be a need for a panel of combination adjuvants for specific disease targets, routes of delivery and/or populations. As recently described [128], depending on whether mainly humoral or cell-mediated immunity is required to induce protection against a pathogen, a TLR4 or TLR3 agonist might be selected to tailor the response. In addition, the choice of delivery vehicle should depend on the route of immunization, mucosal or parenteral. When targeting specific populations such as neonates or the elderly, adjuvant selection should take the expression levels of PRRs in these populations into consideration. As more information becomes available on the efficacy, safety and mechanism of action, we can expect an increase in the number of licensed vaccines containing various combination adjuvants.

\section{Acknowledgments}

Research in the authors' laboratories is funded from a variety of funding agencies including the Canadian Institutes of Health Research (CIHR), the National Science and Engineering Research Council (NSERC), the Saskatchewan Health Research Foundation (SHRF), the Alberta Livestock and Meat Agency (ALMA), the Saskatchewan Agriculture Development Fund (ADF), the Pan-Provincial Vaccine Enterprise and the Krembil Foundation. The manuscript was published with permission of the Director of VIDO as manuscript \#675. 


\section{Author Contributions}

B. Levast wrote the ISCOM and IC31 sections, S. Awate wrote the adjuvant systems section, L. Babiuk critically read the review, G. Mutwiri wrote the Montanide section, V. Gerdts wrote the introduction, IC31 and triple adjuvant sections and S. van Drunen Littel-van den Hurk wrote the liposomes, nanoemulsions and conclusions sections and was responsible for the final submission.

\section{Conflicts of Interest}

The authors declare no conflict of interest.

\section{References}

1. Christensen, D.; Korsholm, K.S.; Andersen, P.; Agger, E.M. Cationic liposomes as vaccine adjuvants. Expert Rev. Vaccines 2012, 10, 513-521.

2. Korsholm, K.S.; Andersen, P.L.; Christensen, D. Cationic liposomal vaccine adjuvants in animal challenge models: Overview and current clinical status. Expert Rev. Vaccines 2012, 11, 561-577.

3. Gall, D. The adjuvant activity of aliphatic nitrogenous bases. Immunology 1966, 11, 369-386.

4. Stanfield, J.P.; Gall, D.; Bracken, P.M. Single-dose antenatal tetanus immunisation. Lancet 1973, $1,215-219$.

5. Veronesi, R.; Correa, A.; Alterio, D. Single dose immunization against tetanus. Promising results in human trials. Rev. Inst. Med. Trop. Sao Paulo 1970, 12, 46-54.

6. Van Donkersgoed, J.; McCartney, D.; van Drunen Littel-van den Hurk, S. Efficacy of an experimental BHV-1 subunit giv vaccine in beef calves challenged with BHV-1 in aerosol. Can. J. Vet. Res. 1996, 60, 55-58.

7. Davidsen, J.; Rosenkrands, I.; Christensen, D.; Vangala, A.; Kirby, D.; Perrie, Y.; Agger, E.M.; Andersen, P. Characterization of cationic liposomes based on dimethyldioctadecylammonium and synthetic cord factor from M. tuberculosis (trehalose 6,6'-dibehenate)-A novel adjuvant inducing both strong CMI and antibody responses. Biochim. Biophys. Acta 2005, 1718, 22-31.

8. Henriksen-Lacey, M.; Christensen, D.; Bramwell, V.W.; Lindenstrom, T.; Agger, E.M.; Andersen, P.; Perrie, Y. Comparison of the depot effect and immunogenicity of liposomes based on dimethyldioctadecylammonium (DDA), 3-beta-[ $N$-( $N^{\prime}, N^{\prime}$-dimethylaminoethane)carbomyl] cholesterol (DC-CHOL), and 1,2-dioleoyl-3-trimethylammonium propane (DOTAP): Prolonged liposome retention mediates stronger th1 responses. Mol. Pharm. 2011, 8, 153-161.

9. Kamath, A.T.; Rochat, A.F.; Christensen, D.; Agger, E.M.; Andersen, P.; Lambert, P.H.; Siegrist, C.A. A liposome-based mycobacterial vaccine induces potent adult and neonatal multifunctional $\mathrm{T}$ cells through the exquisite targeting of dendritic cells. PLoS One 2009, 4, e5771.

10. Milicic, A.; Kaur, R.; Reyes-Sandoval, A.; Tang, C.K.; Honeycutt, J.; Perrie, Y.; Hill, A.V. Small cationic DDA:TDB liposomes as protein vaccine adjuvants obviate the need for TLR agonists in inducing cellular and humoral responses. PLoS One 2012, 7, e34255. 
11. Agger, E.M.; Cassidy, J.P.; Brady, J.; Korsholm, K.S.; Vingsbo-Lundberg, C.; Andersen, P. Adjuvant modulation of the cytokine balance in Mycobacterium tuberculosis subunit vaccines; immunity, pathology and protection. Immunology 2008, 124, 175-185.

12. Langermans, J.A.; Doherty, T.M.; Vervenne, R.A.; van der Laan, T.; Lyashchenko, K.; Greenwald, R.; Agger, E.M.; Aagaard, C.; Weiler, H.; van Soolingen, D.; et al. Protection of macaques against Mycobacterium tuberculosis infection by a subunit vaccine based on a fusion protein of antigen 85B and ESAT-6. Vaccine 2005, 23, 2740-2750.

13. Korsholm, K.S.; Petersen, R.V.; Agger, E.M.; Andersen, P. T-helper 1 and T-helper 2 adjuvants induce distinct differences in the magnitude, quality and kinetics of the early inflammatory response at the site of injection. Immunology 2010, 129, 75-86.

14. Solodin, I.; Brown, C.S.; Bruno, M.S.; Chow, C.Y.; Jang, E.H.; Debs, R.J.; Heath, T.D. A novel series of amphiphilic imidazolinium compounds for in vitro and in vivo gene delivery. Biochemistry 1995, 34, 13537-13544.

15. McLean, J.W.; Fox, E.A.; Baluk, P.; Bolton, P.B.; Haskell, A.; Pearlman, R.; Thurston, G.; Umemoto, E.Y.; McDonald, D.M. Organ-specific endothelial cell uptake of cationic liposome-DNA complexes in mice. Am. J. Physiol. 1997, 273, H387-H404.

16. Zaks, K.; Jordan, M.; Guth, A.; Sellins, K.; Kedl, R.; Izzo, A.; Bosio, C.; Dow, S. Efficient immunization and cross-priming by vaccine adjuvants containing TLR3 or TLR9 agonists complexed to cationic liposomes. J. Immunol. 2006, 176, 7335-7345.

17. Morrey, J.D.; Motter, N.E.; Taro, B.; Lay, M.; Fairman, J. Efficacy of cationic lipid-DNA complexes (CLDC) on hepatitis B virus in transgenic mice. Antivir. Res. 2008, 79, 71-79.

18. Lay, M.; Callejo, B.; Chang, S.; Hong, D.K.; Lewis, D.B.; Carroll, T.D.; Matzinger, S.; Fritts, L.; Miller, C.J.; Warner, J.F.; et al. Cationic lipid/DNA complexes (JVRS-100) combined with influenza vaccine (Fluzone ${ }^{\circledR}$ ) increases antibody response, cellular immunity, and antigenically drifted protection. Vaccine 2009, 27, 3811-3820.

19. Bernstein, D.I.; Farley, N.; Bravo, F.J.; Earwood, J.; McNeal, M.; Fairman, J.; Cardin, R. The adjuvant CLDC increases protection of a herpes simplex type 2 glycoprotein $\mathrm{D}$ vaccine in guinea pigs. Vaccine 2010, 28, 3748-3753.

20. Gowen, B.B.; Fairman, J.; Dow, S.; Troyer, R.; Wong, M.H.; Jung, K.H.; Melby, P.C.; Morrey, J.D. Prophylaxis with cationic liposome-DNA complexes protects hamsters from phleboviral disease: Importance of liposomal delivery and CPG motifs. Antivir. Res. 2009, 81, 37-46.

21. Troyer, R.M.; Propst, K.L.; Fairman, J.; Bosio, C.M.; Dow, S.W. Mucosal immunotherapy for protection from pneumonic infection with francisella tularensis. Vaccine 2009, 27, 4424-4433.

22. Jones, A.; Bosio, C.; Duffy, A.; Goodyear, A.; Schriefer, M.; Dow, S. Protection against pneumonic plague following oral immunization with a non-replicating vaccine. Vaccine 2010, 28, 5924-5929.

23. Hansen, C.; Jespersen, S.; Te, D.D.; Rodrigues, C.M.; Janitzek, C.M.; Vinner, L.; Katzenstein, T.L.; Andersen, P.; Kromann, I.; Andreasen, L.V.; et al. Therapeutic vaccination using cationic liposome-adjuvanted HIV type 1 peptides representing HLA-supertype-restricted subdominant $\mathrm{T}$ cell epitopes: Safety, immunogenicity and feasibility in guinea-bissau. AIDS Res. Hum. Retrovir. 2013, doi:10.1089/AID.2013.0076. 
24. Schnurr, M.; Orban, M.; Robson, N.C.; Shin, A.; Braley, H.; Airey, D.; Cebon, J.; Maraskovsky, E.; Endres, S. Iscomatrix adjuvant induces efficient cross-presentation of tumor antigen by dendritic cells via rapid cytosolic antigen delivery and processing via tripeptidyl peptidase II. J. Immunol. 2009, 182, 1253-1259.

25. Drane, D.; Maraskovsky, E.; Gibson, R.; Mitchell, S.; Barnden, M.; Moskwa, A.; Shaw, D.; Gervase, B.; Coates, S.; Houghton, M.; et al. Priming of $\mathrm{CD}^{+}$and $\mathrm{CD} 8^{+} \mathrm{T}$ cell responses using a HCV core iscomatrix vaccine: A phase I study in healthy volunteers. Hum. Vaccines 2009, 5, 151-157.

26. Lovgren Bengtsson, K.; Morein, B.; Osterhaus, A.D. Iscom technology-based matrix m adjuvant: Success in future vaccines relies on formulation. Expert Rev. Vaccines 2011, 10, 401-403.

27. Eriksson, A.M.; Schon, K.M.; Lycke, N.Y. The cholera toxin-derived CTA1-DD vaccine adjuvant administered intranasally does not cause inflammation or accumulate in the nervous tissues. J. Immunol. 2004, 173, 3310-3319.

28. Lycke, N. From toxin to adjuvant: The rational design of a vaccine adjuvant vector, CTA1-DD/ iscom. Cell Microbiol. 2004, 6, 23-32.

29. Eliasson, D.G.; Helgeby, A.; Schon, K.; Nygren, C.; El-Bakkouri, K.; Fiers, W.; Saelens, X.; Lovgren, K.B.; Nystrom, I.; Lycke, N.Y. A novel non-toxic combined CTA1-DD and iscoms adjuvant vector for effective mucosal immunization against influenza virus. Vaccine 2011, 29, 3951-3961.

30. Jacobs, C.; Duewell, P.; Heckelsmiller, K.; Wei, J.; Bauernfeind, F.; Ellermeier, J.; Kisser, U.; Bauer, C.A.; Dauer, M.; Eigler, A.; et al. An iscom vaccine combined with a TLR9 agonist breaks immune evasion mediated by regulatory $\mathrm{T}$ cells in an orthotopic model of pancreatic carcinoma. Int. J. Cancer 2011, 128, 897-907.

31. Kostetsky, E.Y.; Sanina, N.M.; Mazeika, A.N.; Tsybulsky, A.V.; Vorobyeva, N.S.; Shnyrov, V.L. Tubular immunostimulating complex based on cucumarioside A2-2 and monogalactosyldiacylglycerol from marine macrophytes. J. Nanobiotechnol. 2011, 9, 35.

32. Sanina, N.M.; Kostetsky, E.Y.; Shnyrov, V.L.; Tsybulsky, A.V.; Novikova, O.D.; Portniagina, O.Y.; Vorobieva, N.S.; Mazeika, A.N.; Bogdanov, M.V. The influence of monogalactosyldiacylglycerols from different marine macrophytes on immunogenicity and conformation of protein antigen of tubular immunostimulating complex. Biochimie 2012, 94, 1048-1056.

33. Bayry, J.; Prabhudas, K.; Gopalakrishna, S.; Patil, P.K.; Ramakrishna, C.; Misra, L.D.; Suryanarayana, V.V. Protective immune response to $16 \mathrm{kDa}$ immunoreactive recombinant protein encoding the C-terminal VP1 portion of foot and mouth disease virus type Asia 1. Microbiol. Immunol. 1999, 43, 765-771.

34. Kamath, A.T.; Rochat, A.-F.; Valenti, M.P.; Agger, E.M.; Lingnau, K.; Andersen, P.; Lambert, P.-H.; Siegrist, C.-A. Adult-like anti-mycobacterial $\mathrm{T}$ cell and in vivo dendritic cell responses following neonatal immunization with Ag85B-ESAT-6 in the IC $31^{\circledR}$ adjuvant. PLoS One 2008, 3, e3683.

35. Aagaard, C.; Hoang, T.T.K.T.; Izzo, A.; Billeskov, R.; Troudt, J.; Arnett, K.; Keyser, A.; Elvang, T.; Andersen, P.; Dietrich, J. Protection and polyfunctional T cells induced by Ag85B-TB10.4/IC31 ${ }^{\circledR}$ against Mycobacterium tuberculosis is highly dependent on the antigen dose. PLoS One 2009, 4, e5930. 
36. Lin, P.L.; Dietrich, J.; Tan, E.; Abalos, R.M.; Burgos, J.; Bigbee, C.; Bigbee, M.; Milk, L.; Gideon, H.P.; Rodgers, M.; et al. The multistage vaccine H56 boosts the effects of BCG to protect cynomolgus macaques against active tuberculosis and reactivation of latent Mycobacterium tuberculosis infection. J. Clin. Investig. 2012, 122, 303-314.

37. Van Dissel, J.T.; Arend, S.M.; Prins, C.; Bang, P.; Tingskov, P.N.; Lingnau, K.; Nouta, J.; Klein, M.R.; Rosenkrands, I.; Ottenhoff, T.H.M.; et al. Ag85B-ESAT-6 adjuvanted with IC31 ${ }^{\circledR}$ promotes strong and long-lived Mycobacterium tuberculosis specific $\mathrm{T}$ cell responses in naive human volunteers. Vaccine 2010, 28, 3571-3581.

38. Van Dissel, J.T.; Soonawala, D.; Joosten, S.A.; Prins, C.; Arend, S.M.; Bang, P.; Tingskov, P.N.; Lingnau, K.; Nouta, J.; Hoff, S.T.; et al. Ag85B-ESAT-6 adjuvanted with IC31 ${ }^{\circledR}$ promotes strong and long-lived Mycobacterium tuberculosis specific T cell responses in volunteers with previous bcg vaccination or tuberculosis infection. Vaccine 2011, 29, 2100-2109.

39. Riedl, K.; Riedl, R.; von Gabain, A.; Nagy, E.; Lingnau, K. The novel adjuvant IC $31^{\circledR}$ strongly improves influenza vaccine-specific cellular and humoral immune responses in young adult and aged mice. Vaccine 2008, 26, 3461-3468.

40. Wizel, B.; Persson, J.; Thorn, K.; Nagy, E.; Harandi, A.M. Nasal and skin delivery of IC $31^{\circledR}$-adjuvanted recombinant HSV-2 gD protein confers protection against genital herpes. Vaccine 2012, 30, 4361-4368.

41. Bonhoure, F.; Gaucheron, J. Montanide ISA 51 VG as adjuvant for human vaccines. J. Immunother. 2006, 29, 647-648.

42. Langermans, J.A.; Hensmann, M.; van Gijlswiik, M.; Zhang, D.; Pan, W.; Giersing, B.K.; Locke, E.; Dubovsk, F.; Wittes, J.; Thomas, A.W. Preclinical evaluation of a chimeric malaria vaccine candidate in montanide ISA $720^{\circledR}$ : Immunogenicity and safety in rhesus macaques. Hum. Vaccines 2006, 2, 222-226.

43. Langermans, J.A.; Schmidt, A.; Vervenne, R.A.; Birkett, A.J.; Calvo-Calle, J.M.; Hensmann, M.; Thornton, G.B.; Dubovsky, F.; Weiler, H.; Nardin, E.; et al. Effect of adjuvant on reactogenicity and long-term immunogenicity of the malaria vaccine ICC-1132 in macaques. Vaccine 2005, 23, 4935-4943.

44. Chianese-Bullock, K.A.; Pressley, J.; Garbee, C.; Hibbitts, S.; Murphy, C.; Yamshchikov, G.; Petroni, G.R.; Bissonette, E.A.; Neese, P.Y.; Grosh, W.W.; et al. MAGE-A1-, MAGE-A10-, and gp100-derived peptides are immunogenic when combined with granulocyte-macrophage colony-stimulating factor and montanide ISA-51 adjuvant and administered as part of a multipeptide vaccine for melanoma. J. Immunol. 2005, 174, 3080-3086.

45. Hersey, P.; Menzies, S.W.; Coventry, B.; Nguyen, T.; Farrelly, M.; Collins, S.; Hirst, D.; Johnson, H. Phase I/II study of immunotherapy with T-cell peptide epitopes in patients with stage IV melanoma. Cancer Immunol. Immunother. 2005, 54, 208-218.

46. Markovic, S.N.; Suman, V.J.; Ingle, J.N.; Kaur, J.S.; Pitot, H.C.; Loprinzi, C.L.; Rao, R.D.; Creagan, E.T.; Pittelkow, M.R.; Allred, J.B.; et al. Peptide vaccination of patients with metastatic melanoma: Improved clinical outcome in patients demonstrating effective immunization. Am. J. Clin. Oncol. 2006, 29, 352-360. 
47. Sabbatini, P.J.; Tsuji, T.; Ferran, L.; Ritter, E.; Sedrak, C.; Tuballes, K.; Jungbluth, A.A.; Ritter, G.; Aghajanian, C.; Bell-McGuinn, K.; et al. Phase I trial of overlapping long peptides from a tumor self-antigen and poly-ICLC shows rapid induction of integrated immune response in ovarian cancer patients. Clin. Cancer Res. 2012, 18, 6497-6508.

48. Goldinger, S.M.; Dummer, R.; Baumgaertner, P.; Mihic-Probst, D.; Schwarz, K.; Hammann-Haenni, A.; Willers, J.; Geldhof, C.; Prior, J.O.; Kündig, T.M.; et al. Nano-particle vaccination combined with TLR-7 and -9 ligands triggers memory and effector CD8 ${ }^{+}$T-cell responses in melanoma patients. Eur. J. Immunol. 2012, 42, 3049-3061.

49. Karbach, J.; Gnjatic, S.; Bender, A.; Neumann, A.; Weidmann, E.; Yuan, J.; Ferrara, C.A.; Hoffmann, E.; Old, L.J.; Altorki, N.K.; et al. Tumor-reactive $\mathrm{CD} 8^{+}$T-cell responses after vaccination with NY-ESO-1 peptide, CpG 7909 and montanide ${ }^{\circledR}$ ISA-51: Association with survival. Int. J. Cancer 2010, 126, 909-918.

50. Kuball, J.; de Boer, K.; Wagner, E.; Wattad, M.; Antunes, E.; Weeratna, R.D.; Vicari, A.P.; Lotz, C.; van Dorp, S.; Hol, S.; et al. Pitfalls of vaccinations with WT1-, proteinase3- and MUC1-derived peptides in combination with MontanideISA51 and CpG7909. Cancer Immunol. Immunother. 2010, 60, 161-171.

51. Aguilar, F.F.; Barranco, J.J.; Fuentes, E.B.; Aguilera, L.C.; Saez, Y.L.; Santana, M.D.; Vazquez, E.P.; Baker, R.B.; Acosta, O.R.; Perez, H.G.; et al. Very small size proteoliposomes (VSSP) and montanide combination enhance the humoral immuno response in a gnrh based vaccine directed to prostate cancer. Vaccine 2012, 30, 6595-6599.

52. Li, H.; Qian, Z.M. Transferrin/transferrin receptor-mediated drug delivery. Med. Res. Rev. 2002, 22, 225-250.

53. Buschle, M.; Schmidt, W.; Zauner, W.; Mechtler, K.; Trska, B.; Kirlappos, H.; Birnstiel, M.L. Transloading of tumor antigen-derived peptides into antigen-presenting-cells. Proc. Natl. Acad. Sci. USA 1997, 94, 3256-3261.

54. Mattner, F.; Fleitmann, J.-K.; Lingnau, K.; Schmidt, W.; Egyed, A.; Fritz, J.; Zauner, W.; Wittmann, B.; Gorny, I.; Berger, M.; et al. Vaccination with poly-l-arginine as immunostimulant for peptide vaccines: Induction of potent and long-lasting T-cell responses against cancer antigens. Cancer Res. 2002, 62, 1477-1480.

55. Lingnau, K.; Egyed, A.; Schellack, C.; Mattner, F.; Buschle, M.; Schmidt, W. Poly-L-arginine synergizes with oligodeoxynucleotides containing CpG-motifs ( $\mathrm{CpG}$ ODN) for enhanced and prolonged immune responses and prevents the $\mathrm{CpG}$ ODN-induced systemic release of pro-inflammatory cytokines. Vaccine 2002, 20, 3498-3508.

56. Fritz, J.H.; Brunner, S.; Birnstiel, M.L.; Buschle, M.; Gabain, A.; Mattner, F.; Zauner, W. The artificial antimicrobial peptide KLKLLLLLKLK induces predominantly a Th2-type immune response to co-injected antigens. Vaccine 2004, 22, 3274-3284.

57. Lingnau, K.; Riedl, K.; von Gabain, A. IC $31^{\circledR}$ and IC30, novel types of vaccine adjuvant based on peptide delivery systems. Expert Rev. Vaccines 2007, 6, 741-746.

58. Sparwasser, T.; Miethke, T.; Lipford, G.; Borschert, K.; Hacker, H.; Heeg, K.; Wagner, H. Bacterial DNA causes septic shock. Nature 1997, 386, 336-337. 
59. Schellack, C.; Prinz, K.; Egyed, A.; Fritz, J.R.H.; Wittmann, B.; Ginzler, M.; Swatosch, G.; Zauner, W.; Kast, C.; Akira, S.; et al. IC31, a novel adjuvant signaling via TLR9, induces potent cellular and humoral immune responses. Vaccine 2006, 24, 5461-5472.

60. Aichinger, M.C.; Ginzler, M.; Weghuber, J.; Zimmermann, L.; Riedl, K.; Schutz, G.; Nagy, E.; von Gabain, A.; Schweyen, R.; Henics, T. Adjuvating the adjuvant: Facilitated delivery of an immunomodulatory oligonucleotide to TLR9 by a cationic antimicrobial peptide in dendritic cells. Vaccine 2011, 29, 426-436.

61. Steinman, R.M. The dendritic cell system and its role in immunogenicity. Annu. Rev. Immunol. 1991, 9, 271-296.

62. Salvador, A.; Igartua, M.; Hernandez, R.M.; Pedraz, J.L. Combination of immune stimulating adjuvants with poly(lactide-co-glycolide) microspheres enhances the immune response of vaccines. Vaccine 2012, 30, 589-596.

63. Salvador, A.; Igartua, M.; Hernandez, R.M.; Pedraz, J.L. An overview on the field of micro- and nano-technologies for synthetic peptide-based vaccines. J. Drug Deliv. 2011, 2011, Article ID 181646.

64. Wieczorek, M.; Jenssen, H.; Kindrachuk, J.; Scott, W.R.; Elliott, M.; Hilpert, K.; Cheng, J.T.; Hancock, R.E.; Straus, S.K. Structural studies of a peptide with immune modulating and direct antimicrobial activity. Chem. Biol. 2010, 17, 970-980.

65. Cherkasov, A.; Hilpert, K.; Jenssen, H.; Fjell, C.D.; Waldbrook, M.; Mullaly, S.C.; Volkmer, R.; Hancock, R.E. Use of artificial intelligence in the design of small peptide antibiotics effective against a broad spectrum of highly antibiotic-resistant superbugs. ACS Chem. Biol. 2009, 4, 65-74.

66. Jenssen, H.; Hamill, P.; Hancock, R.E. Peptide antimicrobial agents. Clin. Microbiol. Rev. 2006, 19, 491-511.

67. Eng, N.F.; Garlapati, S.; Gerdts, V.; Potter, A.; Babiuk, L.A.; Mutwiri, G.K. The potential of polyphosphazenes for delivery of vaccine antigens and immunotherapeutic agents. Curr. Drug Deliv. 2010, 7, 13-20.

68. Mutwiri, G.; Benjamin, P.; Soita, H.; Townsend, H.; Yost, R.; Roberts, B.; Andrianov, A.K.; Babiuk, L.A. Poly[di(sodium carboxylatoethylphenoxy)phosphazene] (PCEP) is a potent enhancer of mixed Th1/Th2 immune responses in mice immunized with influenza virus antigens. Vaccine 2007, 25, 1204-1213.

69. Kindrachuk, J.; Jenssen, H.; Elliott, M.; Townsend, R.; Nijnik, A.; Lee, S.F.; Gerdts, V.; Babiuk, L.A.; Halperin, S.A.; Hancock, R.E. A novel vaccine adjuvant comprised of a synthetic innate defence regulator peptide and $\mathrm{CpG}$ oligonucleotide links innate and adaptive immunity. Vaccine 2009, 27, 4662-4671.

70. Dybvig, T. Host defence peptides BMAP-27 and BMAP-28 Down-Regulate Proliferation of Porcine T Cells through Induction of T Cell Anergy. M.S. Thesis, University of Saskatchewan, Saskatoon, SK, Canada, 2010.

71. Garlapati, S.; Eng, N.F.; Wilson, H.L.; Buchanan, R.; Mutwiri, G.K.; Babiuk, L.A.; Gerdts, V. Pcpp (poly[di(carboxylatophenoxy)-phosphazene]) microparticles co-encapsulating ovalbumin and $\mathrm{CpG}$ oligo-deoxynucleotides are potent enhancers of antigen specific Th1 immune responses in mice. Vaccine 2010, 28, 8306-8314. 
72. Kovacs-Nolan, J.; Latimer, L.; Landi, A.; Jenssen, H.; Hancock, R.E.; Babiuk, L.A.; van Drunen Littel-van den Hurk, S. The novel adjuvant combination of CpG ODN, indolicidin and polyphosphazene induces potent antibody- and cell-mediated immune responses in mice. Vaccine 2009, 27, 2055-2064.

73. Kovacs-Nolan, J.; Mapletoft, J.W.; Latimer, L.; Babiuk, L.A.; Hurk, S. CpG oligonucleotide, host defense peptide and polyphosphazene act synergistically, inducing long-lasting, balanced immune responses in cattle. Vaccine 2009, 27, 2048-2054.

74. Kovacs-Nolan, J.; Mapletoft, J.W.; Lawman, Z.; Babiuk, L.A.; van Drunen Littel-van den Hurk, S. Formulation of bovine respiratory syncytial virus fusion protein with cpg oligodeoxynucleotide, cationic host defence peptide and polyphosphazene enhances humoral and cellular responses and induces a protective type 1 immune response in mice. J. Gener. Virol. 2009, 90, 1892-1905.

75. Polewicz, M.; Gracia, A.; Buchanan, R.; Strom, S.; Halperin, S.A.; Potter, A.A.; Babiuk, L.A.; Gerdts, V. Influence of maternal antibodies on active pertussis toxoid immunization of neonatal mice and piglets. Vaccine 2011, 29, 7718-7726.

76. Gracia, A.; Polewicz, M.; Halperin, S.A.; Hancock, R.E.; Potter, A.A.; Babiuk, L.A.; Gerdts, V. Antibody responses in adult and neonatal BALB/c mice to immunization with novel Bordetella pertussis vaccine formulations. Vaccine 2011, 29, 1595-1604.

77. Polewicz, M.; Gracia, A.; Garlapati, S.; van Kessel, J.; Strom, S.; Halperin, S.A.; Hancock, R.E.; Potter, A.A.; Babiuk, L.A.; Gerdts, V. Novel vaccine formulations against pertussis offer earlier onset of immunity and provide protection in the presence of maternal antibodies. Vaccine 2013, 31, 3148-3155.

78. Garlapati, S.; Garg, R.; Brownlie, R.; Latimer, L.; Simko, E.; Hancock, R.E.; Babiuk, L.A.; Gerdts, V.; Potter, A.; van Drunen Littel-van den Hurk, S. Enhanced immune responses and protection by vaccination with respiratory syncytial virus fusion protein formulated with $\mathrm{CpG}$ oligodeoxynucleotide and innate defense regulator peptide in polyphosphazene microparticles. Vaccine 2012, 30, 5206-5214.

79. Garg, R.; Latimer, L.; Simko, E.; Gerdts, V.; Potter, A.; van den Hurk, S. Induction of mucosal immunity and protection by intranasal immunization with a respiratory syncytial virus subunit vaccine formulation. J. Gener. Virol. 2014, 95, 301-306.

80. Shim, D.H.; Ko, H.J.; Volker, G.; Potter, A.A.; Mutwiri, G.; Babiuk, L.A.; Kweon, M.N. Efficacy of poly[di(sodium carboxylatophenoxy)phosphazene] (PCPP) as mucosal adjuvant to induce protective immunity against respiratory pathogens. Vaccine 2010, 28, 2311-2317.

81. Garçon, N.; van Mechelen, M. Recent clinical experience with vaccines using MPL- and QS-21-containing adjuvant systems. Expert Rev. Vaccines 2011, 10, 471-486.

82. Bourne, N.; Milligan, G.N.; Stanberry, L.R.; Stegall, R.; Pyles, R.B. Impact of immunization with glycoprotein D2/AS04 on herpes simplex virus type 2 shedding into the genital tract in guinea pigs that become infected. J. Infect. Dis. 2005, 192, 2117-2123.

83. Stanberry, L.R.; Spruance, S.L.; Cunningham, A.L.; Bernstein, D.I.; Mindel, A.; Sacks, S.; Tyring, S.; Aoki, F.Y.; Slaoui, M.; Denis, M.; et al. Glycoprotein-D-adjuvant vaccine to prevent genital herpes. N. Eng. J. Med. 2002, 347, 1652-1661. 
84. Belshe, R.B.; Leone, P.A.; Bernstein, D.I.; Wald, A.; Levin, M.J.; Stapleton, J.T.; Gorfinkel, I.; Morrow, R.L.A.; Ewell, M.G.; Stokes-Riner, A.; et al. Efficacy results of a trial of a herpes simplex vaccine. N. Eng. J. Med. 2012, 366, 34-43.

85. Didierlaurent, A.M.; Morel, S.; Lockman, L.; Giannini, S.L.; Bisteau, M.; Carlsen, H.; Kielland, A.; Vosters, O.; Vanderheyde, N.; Schiavetti, F.; et al. AS04, an aluminum salt- and TLR4 agonist-based adjuvant system, induces a transient localized innate immune response leading to enhanced adaptive immunity. J. Immunol. 2009, 183, 6186-6197.

86. Segal, L.; Wilby, O.K.; Willoughby, C.R.; Veenstra, S.P.; Deschamps, M. Evaluation of the intramuscular administration of cervarix ${ }^{\mathrm{TM}}$ vaccine on fertility, pre- and post-natal development in rats. Reprod. Toxicol. 2011, 31, 111-120.

87. Traber, M.G. Vitamin E regulatory mechanisms. Annu. Rev. Nutr. 2007, 27, 347-362.

88. Do, R.; Kiss, R.S.; Gaudet, D.; Engert, J.C. Squalene synthase: A critical enzyme in the cholesterol biosynthesis pathway. Clin. Genet. 2009, 75, 19-29.

89. Akers, M.J. Excipient-drug interactions in parenteral formulations. J. Pharm. Sci. 2002, 91, 2283-2300.

90. Morel, S.; Didierlaurent, A.; Bourguignon, P.; Delhaye, S.; Baras, B.; Jacob, V.; Planty, C.; Elouahabi, A.; Harvengt, P.; Carlsen, H.; et al. Adjuvant system AS03 containing $\alpha$-tocopherol modulates innate immune response and leads to improved adaptive immunity. Vaccine 2011, 29, 2461-2473.

91. Moris, P.; van der Most, R.; Leroux-Roels, I.; Clement, F.; Dramé, M.; Hanon, E.; Leroux-Roels, G.; van Mechelen, M. H5N1 influenza vaccine formulated with AS03A induces strong cross-reactive and polyfunctional CD4 T-cell responses. J. Clin. Immunol. 2011, 31, 443-454.

92. Newman, M.J.; Wu, J.Y.; Gardner, B.H.; Munroe, K.J.; Leombruno, D.; Recchia, J.; Kensil, C.R.; Coughlin, R.T. Saponin adjuvant induction of ovalbumin-specific $\mathrm{CD} 8^{+}$cytotoxic T lymphocyte responses. J. Immunol. 1992, 148, 2357-2362.

93. Newman, M.J.; Wu, J.Y.; Gardner, B.H.; Anderson, C.A.; Kensil, C.R.; Recchia, J.; Coughlin, R.T.; Powell, M.F. Induction of cross-reactive cytotoxic T-lymphocyte responses specific for HIV-1 gp120 using saponin adjuvant (QS-21) supplemented subunit vaccine formulations. Vaccine 1997, 15, 1001-1007.

94. Newman, M.J.; Wu, J.Y.; Coughlin, R.T.; Murphy, C.I.; Seals, J.R.; Wyand, M.S.; Kensil, C.R. Immunogenicity and toxicity testing of an experimental HIV-1 vaccine in nonhuman primates. AIDS Res. Hum. Retrovir. 1992, 8, 1413-1418.

95. Garcon, N.; Heppner, D.G.; Cohen, J. Development of RTS,S/AS02: A purified subunit-based malaria vaccine candidate formulated with a novel adjuvant. Expert Rev. Vaccines 2003, 2, 231-238.

96. Stoute, J.A.; Slaoui, M.; Heppner, D.G.; Momin, P.; Kester, K.E.; Desmons, P.; Wellde, B.T.; Garcon, N.; Krzych, U.; Marchand, M.; et al. A preliminary evaluation of a recombinant circumsporozoite protein vaccine against Plasmodium falciparum malaria. N. Eng. J. Med. 1997, 336, 86-91.

97. Schwarz, T.F.; Kocken, M.; Petäjä, T.; Einstein, M.H.; Spaczynski, M.; Louwers, J.A.; Pedersen, C.; Levin, M.; Zahaf, T.; Poncelet, S.; et al. Correlation between levels of human papillomavirus (HPV)-16 and 18 antibodies in serum and cervicovaginal secretions in girls and women vaccinated with the HPV-16/18 AS04-adjuvanted vaccine. Hum. Vaccines 2010, 6, 1054-1061. 
98. Wheeler, C.M.; Castellsague, X.; Garland, S.M.; Szarewski, A.; Paavonen, J.; Naud, P.; Salmeron, J.; Chow, S.-N.; Apter, D.; Kitchener, H.; et al. Cross-protective efficacy of HPV-16/18 AS04-adjuvanted vaccine against cervical infection and precancer caused by non-vaccine oncogenic hpv types: 4-year end-of-study analysis of the randomised, double-blind patricia trial. Lancet Oncol. 2012, 13, 100-110.

99. Sow, P.S.; Watson-Jones, D.; Kiviat, N.; Changalucha, J.; Mbaye, K.D.; Brown, J.; Bousso, K.; Kavishe, B.; Andreasen, A.; Toure, M.; et al. Safety and immunogenicity of human papillomavirus-16/18 AS04-adjuvanted vaccine: A randomized trial in 10-25-year-old HIV-seronegative african girls and young women. J. Infect. Diseases 2013, 207, 1753-1763.

100. Roteli-Martins, C.M.; Naud, P.; de Borba, P.; Teixeira, J.C.; de Carvalho, N.S.; Zahaf, T.; Sanchez, N.; Geeraerts, B.; Descamps, D. Sustained immunogenicity and efficacy of the HPV-16/18 AS04-adjuvanted vaccine: Up to 8.4 years of follow-up. Hum. Vaccines Immunother. 2012, 8, 390-397.

101. Pedersen, C.; Breindahl, M.; Aggarwal, N.; Berglund, J.; Oroszlan, G.; Silfverdal, S.A.; Szuts, P.; O’Mahony, M.; David, M.-P.; Dobbelaere, K.; et al. Randomized trial: Immunogenicity and safety of coadministered human papillomavirus-16/18 AS04-adjuvanted vaccine and combined hepatitis A and B vaccine in girls. J. Adolesc. Health 2012, 50, 38-46.

102. Kong, N.C.T.; Beran, J.; Kee, S.A.; Miguel, J.L.; Sanchez, C.; Bayas, J.M.; Vilella, A.; Calbo-Torrecillas, F.; Lopez de Novales, E.; Srinivasa, K.; et al. A new adjuvant improves the immune response to hepatitis B vaccine in hemodialysis patients. Kidney Int. 2007, 73, 856-862.

103. Chu, D.W.-S.; Hwang, S.-J.; Lim, F.S.; Oh, H.M.L.; Thongcharoen, P.; Yang, P.-C.; Bock, H.L.; Drame, M.; Gillard, P.; Hutagalung, Y.; et al. Immunogenicity and tolerability of an AS03A-adjuvanted prepandemic influenza vaccine: A phase III study in a large population of asian adults. Vaccine 2009, 27, 7428-7435.

104. Díez-Domingo, J.; Garcés-Sanchez, M.; Baldó, J.-M.; Planelles, M.V.; Ubeda, I.; JuBert, A.; Marés, J.; Moris, P.; Garcia-Corbeira, P.; Dramé, M.; et al. Immunogenicity and safety of H5N1 A/Vietnam/1194/2004 (Clade 1) AS03-adjuvanted prepandemic candidate influenza vaccines in children aged 3 to 9 years: A phase II, randomized, open, controlled study. Pediatr. Infect. Disease J. 2010, 29, e35-e46.

105. Roman, F.; Vaman, T.; Kafeja, F.; Hanon, E.; van Damme, P. AS03A-adjuvanted influenza a (H1N1) 2009 vaccine for adults up to 85 years of age. Clin. Infect. Dis. 2010, 51, 668-677.

106. Waddington, C.; Andrews, N.; Hoschler, K.; Walker, W.; Oeser, C.; Reiner, A.; John, T.; Wilkins, S.; Casey, M.; Eccleston, P.; et al. Open-label, randomised, parallel-group, multicentre study to evaluate the safety, tolerability and immunogenicity of an AS03(B)/oil-in-water emulsion-adjuvanted (AS03(B)) split-virion versus non-adjuvanted whole-virion H1N1 influenza vaccine in UK children 6 months to 12 years of age. Health Technol. Assess. 2010, 14, 1-130.

107. Garcon, N.; Vaughn, D.W.; Didierlaurent, A.M. Development and evaluation of AS03, an adjuvant system containing $\alpha$-tocopherol and squalene in an oil-in-water emulsion. Expert Rev. Vaccines 2012, 11, 349-366. 
108. Bojang, K.A.; Milligan, P.J.M.; Pinder, M.; Vigneron, L.; Alloueche, A.; Kester, K.E.; Ballou, W.R.; Conway, D.J.; Reece, W.H.H.; Gothard, P.; et al. Efficacy of RTS,S/AS02 malaria vaccine against Plasmodium falciparum infection in semi-immune adult men in the gambia: A randomised trial. Lancet 2001, 358, 1927-1934.

109. Alonso, P.L.; Sacarlal, J.; Aponte, J.J.; Leach, A.; Macete, E.; Aide, P.; Sigauque, B.; Milman, J.; Mandomando, I.; Bassat, Q.; et al. Duration of protection with RTS,S/AS02A malaria vaccine in prevention of Plasmodium falciparum disease in mozambican children: Single-blind extended follow-up of a randomised controlled trial. Lancet 2005, 366, 2012-2018.

110. Leroux-Roels, I.; Leroux-Roels, G.; Ofori-Anyinam, O.; Moris, P.; De Kock, E.; Clement, F.; Dubois, M.-C.; Koutsoukos, M.; Demoitie, M.-A.; Cohen, J.; et al. Evaluation of the safety and immunogenicity of two antigen concentrations of the MTB72F/AS02A candidate tuberculosis vaccine in purified protein derivative-negative adults. Clin. Vaccine Immunol. 2010, 17, 1763-1771.

111. Beran, J.; Hobzova, L.; Wertzova, V.; Kuriyakose, S.; Leyssen, M.; Surquin, M.; Houard, S. Safety and immunogenicity of an investigational adjuvanted hepatitis B vaccine (HB-AS02V) in healthy adults. Hum. Vaccines 2010, 6, 578-584.

112. Tielemans, C.L.; Vlasak, J.; Kosa, D.; Billiouw, J.-M.; Verpooten, G.A.; Mezei, I.; Ryba, M.; Peeters, P.C.; Mat, O.; Jadoul, M.Y.; et al. Immunogenicity and safety of an investigational AS02V-adjuvanted hepatitis $b$ vaccine in patients with renal insufficiency who failed to respond or to maintain antibody levels after prior vaccination: Results of two open, randomized, comparative trials. Vaccine 2011, 29, 1159-1166.

113. Vantomme, V.R.; Dantinne, C.; Amrani, N.; Permanne, P.; Gheysen, D.; Bruck, C.; Stoter, G.; Britten, C.M.; Keilholz, U.; Lamers, C.H.J.; et al. Immunologic analysis of a phase I/II study of vaccination with mage-3 protein combined with the AS02B adjuvant in patients with mage-3positive tumors. J. Immunother. 2004, 27, 124-135.

114. Atanackovic, D.; Altorki, N.K.; Cao, Y.; Ritter, E.; Ferrara, C.A.; Ritter, G.; Hoffman, E.W.; Bokemeyer, C.; Old, L.J.; Gnjatic, S. Booster vaccination of cancer patients with MAGE-A3 protein reveals long-term immunological memory or tolerance depending on priming. Proc. Natl. Acad. Sci. USA 2008, 105, 1650-1655.

115. Stewart, V.A.; McGrath, S.M.; Walsh, D.S.; Davis, S.; Hess, A.S.; Ware, L.A.; Kester, K.E.; Cummings, J.F.; Burge, J.R.; Voss, G.; et al. Pre-clinical evaluation of new adjuvant formulations to improve the immunogenicity of the malaria vaccine RTS,S/AS02A. Vaccine 2006, 24, 6483-6492.

116. Stewart, V.A.; McGrath, S.M.; Dubois, P.M.; Pau, M.G.; Mettens, P.; Shott, J.; Cobb, M.; Burge, J.R.; Larson, D.; Ware, L.A.; et al. Priming with an adenovirus 35-circumsporozoite protein (CS) vaccine followed by RTS,S/AS01B boosting significantly improves immunogenicity to Plasmodium falciparum CS compared to that with either malaria vaccine alone. Infect. Immun. 2007, 75, 2283-2290.

117. Kester, K.E.; Cummings, J.F.; Ofori-Anyinam, O.; Ockenhouse, C.F.; Krzych, U.; Moris, P.; Schwenk, R.; Nielsen, R.A.; Debebe, Z.; Pinelis, E.; et al. Randomized, double-blind, phase 2a trial of falciparum malaria vaccines RTS,S/AS01B and RTS,S/AS02A in malaria-naive adults: Safety, efficacy, and immunologic associates of protection. J. Infect. Dis. 2009, 200, 337-346. 
118. Leroux-Roels, I.; Forgus, S.; de Boever, F.; Clement, F.; Demoitie, M.A.; Mettens, P.; Moris, P.; Ledent, E.; Leroux-Roels, G.; Ofori-Anyinam, O.; et al. Improved $\mathrm{CD} 4^{(+)} \mathrm{T}$ cell responses to Mycobacterium tuberculosis in PPD-negative adults by M72/AS01 as compared to the M72/AS02 and MTB72F/AS02 tuberculosis candidate vaccine formulations: A randomized trial. Vaccine 2013, 31, 2196-2206.

119. Ansong, D.; Asante, K.P.; Vekemans, J.; Owusu, S.K.; Owusu, R.; Brobby, N.A.; Dosoo, D.; Osei-Akoto, A.; Osei-Kwakye, K.; Asafo-Adjei, E.; et al. T cell responses to the RTS,S/AS01(E) and RTS,S/AS02(D) malaria candidate vaccines administered according to different schedules to ghanaian children. PLoS One 2011, 6, e18891.

120. Van Braeckel, E.; Bourguignon, P.; Koutsoukos, M.; Clement, F.; Janssens, M.; Carletti, I.; Collard, A.; Demoitie, M.-A.; Voss, G.; Leroux-Roels, G.; et al. An adjuvanted polyprotein HIV-1 vaccine induces polyfunctional cross-reactive $\mathrm{CD} 4^{+} \mathrm{T}$ cell responses in seronegative volunteers. Clin. Infect. Dis. 2011, 52, 522-531.

121. Pichyangkul, S.; Gettayacamin, M.; Miller, R.S.; Lyon, J.A.; Angov, E.; Tongtawe, P.; Ruble, D.L.; Heppner, D.G., Jr.; Kester, K.E.; Ballou, W.R.; et al. Pre-clinical evaluation of the malaria vaccine candidate $P$. falciparum $\mathrm{MSP}_{42}$ formulated with novel adjuvants or with alum. Vaccine 2004, 22, 3831-3840.

122. Dey, A.K.; Srivastava, I.K. Novel adjuvants and delivery systems for enhancing immune responses induced by immunogens. Expert Rev. Vaccines 2011, 10, 227-251.

123. Schultze, V.; D’Agosto, V.; Wack, A.; Novicki, D.; Zorn, J.; Hennig, R. Safety of MF59 adjuvant. Vaccine 2008, 26, 3209-3222.

124. Stanberry, L.R.; Simon, J.K.; Johnson, C.; Robinson, P.L.; Morry, J.; Flack, M.R.; Gracon, S.; Myc, A.; Hamouda, T.; Baker, J.R., Jr. Safety and immunogenicity of a novel nanoemulsion mucosal adjuvant $\mathrm{W}_{80} 5 \mathrm{EC}$ combined with approved seasonal influenza antigens. Vaccine 2012, 30, 307-316.

125. Baudner, B.C.; Ronconi, V.; Casini, D.; Tortoli, M.; Kazzaz, J.; Singh, M.; Hawkins, L.D.; Wack, A.; O'Hagan, D.T. MF59 emulsion is an effective delivery system for a synthetic TLR4 agonist (E6020). Pharm. Res. 2009, 26, 1477-1485.

126. Singh, M.; Kazzaz, J.; Ugozzoli, M.; Baudner, B.; Pizza, M.; Giuliani, M.; Hawkins, L.D.; Otten, G.; O'Hagan, D.T. MF59 oil-in-water emulsion in combination with a synthetic TLR4 agonist (E6020) is a potent adjuvant for a combination meningococcus vaccine. Hum. Vaccines Immunother. 2012, 8, 486-490.

127. Wack, A.; Baudner, B.C.; Hilbert, A.K.; Manini, I.; Nuti, S.; Tavarini, S.; Scheffczik, H.; Ugozzoli, M.; Singh, M.; Kazzaz, J.; et al. Combination adjuvants for the induction of potent, long-lasting antibody and T-cell responses to influenza vaccine in mice. Vaccine 2008, 26, 552-561.

128. Reed, S.G.; Orr, M.T.; Fox, C.B. Key roles of adjuvants in modern vaccines. Nat. Med. 2013, 19, $1597-1608$. 
129. Li, S.; Rouphael, N.; Duraisingham, S.; Romero-Steiner, S.; Presnell, S.; Davis, C.; Schmidt, D.S.; Johnson, S.E.; Milton, A.; Rajam, G.; et al. Molecular signatures of antibody responses derived from a systems biology study of five human vaccines. Nat. Immunol. 2014, 15, 195-204.

(C) 2014 by the authors; licensee MDPI, Basel, Switzerland. This article is an open access article distributed under the terms and conditions of the Creative Commons Attribution license (http://creativecommons.org/licenses/by/3.0/). 